\title{
INCREASED CAPACITY OF YOUTH THROUGH COMMUNICATION SKILLS IN THE VILLAGE OF BANDUNG REGENCY WARNASARI PANGALENGAN
}

\author{
Elly Komala ${ }^{1}$, Yanti Susila Tresnawati ${ }^{2}$, Winne Mardiani ${ }^{3}$, Qisthy Rabathy ${ }^{4}$ \\ 1,2,3,4 Universitas Pasundan, Bandung, Indonesia \\ 1elly.komala@unpas.ac.id, 22yanti.susila@unpas.ac.id, \\ 3 winne.wardiani@unpas.ac.id 4 qisthyrabathy@unpas.ac.id
}

\begin{abstract}
One of the large and important sector contribution in realizing the goals of national economic development is Youth. Youth have the ability to participate spur national economic growth. The development of small and medium enterprise sector that is managed by the Youth, especially in the village of Warnasari Pangalengan Bandung regency, West Java province. Warnasari village is actually located on a strategic area adjacent to the tourist potential Cileunca. Mountain air and natural beauty which is owned Warnasari, contributed to the development of the tourism sector. It can make Pangalengan Warnasari area as a tourism area.One community empowerment is very important to do in the village Warnasari is to prepare everything, both human resources and infrastructure to manage the natural resources that exist in order to boost the tourism potential there. Communication skills are also needed in relation -menjalin business development, marketing, promotion, etc. - also in the development and empowerment of self - personal branding / self empowering. Target outcomes of the implementation of this program is the creation of skills in verbal communication and non-verbal in both partners, The method used in the implementation of this program, covering namely; training and simulation. In addition to setting method, the team also determined the procedure, step - step. executive team is an expert in the field of environment Pasundan University Bandung, which is experienced in implementing development programs, especially in the field of communications. The most important thing in communication skills is understanding how to communicate in interaction, in this case the communication skills verbal and non-verbal is essential. The results is to gaining communication skills to participate actively in the interaction around it's precisely accurate. And indirectly Communication skills have become the main weapon which is powerful for people to be able to develop the tourism potential in the village Warnasari.
\end{abstract}

Keywords: communication, communication skill

\section{A. Introduction}

Pangalengan is one of the districts in Bandung, a regional agricultural center. The agricultural sector accounted for the largest of the total regional gross domestic product Pangalengan even to the district level, the third-largest contributor after the industrial sector (excluding oil and gas), mining and quarrying (oil 
and gas). Seeing the potential the agricultural sector is a sector that deserves more attention, both from the local government and the farming community itself.

Some types of crops cultivated in Pangalengan, include rice, maize, cassava, sweet potatoes, beans and lentils. For rice and other crops, rice production is still ranked at the bottom. This situation can be understood because the acreage of paddy rice is quite small when compared with the total area planted horticultural. Horticultural crops is excellent in Pangalengan compared with other crops, horticultural crops have seeded the crop sepert potatoes, cabbage, chinese cabbage / cabbage, carrots, tomatoes, squash, onions, peppers and followed yaituh fruit trees, citrus, avocados and banana. For plantation crops such as tea and coffee, strawberries are also earned in District Pangalengan.

Meanwhile, the village is part of the District Warnasari Pangalengan Bandung regency, West Java province. Warnasari village has an area of 2354.119 hectares, situated at an altitude of \pm 1442 meters above sea level and has an average air temperature of $12^{\circ} \mathrm{C}-25^{\circ} \mathrm{C}$. Limit Warnasari Village area is north of the village Pulosari, Pulosari village east, south and west village Margaluyu Pasir Jambu.

Warnasari village has 17 Rukun Warga and 17 villages namely New Taraje, Ciawitali, Cibeunying, Cibunihayu, Cidurian, Cipangisikan, Citiis, Cotton, Kiaracondong, Munjul, Neglasari, Padahurip, Palayangan, Parabon, Sand Ucing, Singkur, and Wanasari. Location TPK Warnasari be in front of the main road in the village of RW 02, Kampung Warnasari Wanasari within \pm 300 meters to the west of the village office Warnasari. TPK placement Warnasari located in the village center location within easy reach by farmers in the north and south as well as facilitate a truck to distribute the collected milk farmers to the location of the milk processing industry.

Based on the above description, Warnasari Village has great potential as a regional agricultural products that can be developed as an agro-industry and agro-tourism. In addition to rice and pulses, which is the result of 
agriculture in general, Warnasari village is also known as a producer of some agricultural products horticulture. In the development of farming in the village Warnasari, essentially required the involvement of actors consisting of various parties, such as product producers, processors, traders, distributors, importers and exporters. These actors are the components or subsystems that form a system of agribusiness. The system, in the coming years is expected to be more a function optimally in order to realize the level of welfare. Therefore, One program development and community empowerment village governments do is through the Youth. The goal is such as economic growth, employment, increasing foreign exchange earnings and economic development of the region, is expected to Youth have the ability to participate spur national economic growth.

Communication is the capital and the key to success in relationships and careers because only with communication a good relationship can be built and nurtured. In certain contexts, communicating requires skill (skill) to be trained and developed.

Communication skills are also needed in relation -menjalin business development, marketing, promotions, etc. - as well as in the development and empowerment of self - personal branding / self empowering. Communication skills are the main skills a must-have to be able to foster a healthy relationship anywhere, in the social environment, schools, businesses, and offices or anywhere.

Skill is the ability of a person has and acquired through training and experience to perform a task (John M Ivancevich, et al 2006, 87). According Cholin Cherry, (Tedjasustina, 1994: 12) communication is a process in which the aim of achieving a better mutual understanding of the issues that are important for all parties concerned. While this type of communication there are two kinds of nonverbal communication and verbal.

Nonverbal communication by Purba, et al (2005: 30), is communication without using words. Simple terms is the first step to distinguish what is called the vocal communication is a follow- 
communication using words.

Meanwhile, verbal communication is communication using words (verb), both orally and in writing (Purba, et al, 2005: 75).

According Cangara (1998: 23), communication skills is the ability of a person to deliver the message to the audience (recipient of the message). Furthermore, according to Nevizond Chatab (2007: 29), communication skills is the ability to make contact via human communication channels or media, so that the message or information can be properly understood. Communication skills is not an innate ability and did not appear suddenly, skill needs to be learned and practiced (Supratiknya, 2003: 12).

There are three kinds of communication skills, verbal, written and visual communication skills. Oral communication skills (oral communication) is the ability to speak (speaking) to be able to explain and present their ideas clearly to various people (audience). Its capabilities include expertise customize how to talk to the communicant different approach and style that fits, and understand the importance of non-verbal cues. This communication takes skill background (background skills) presentations, an understanding of the audience, listening critically, and body language (body language).

Written communication skills (written communication) is the ability to write effectively in the context and for a variety of readers and purpose. This capability includes the ability to write in a different style and approach to the readers or different media. Written communication skills also include electronic communication skills such as writing short message, write and send email, engage in "online discussion forum" (discussion boards), chat rooms, and instant messaging. This communication requires skills such as writing an academic background, expertise revision and editing (editing), critical reading, and presentation of data.

While the non-verbal communication skills (non-verbal communication) is the ability of strengthening the expression of ideas and concepts through the use of body language (body language)gestures (gesture), facial expressions, and tone / voice (tone of voice). Non-verbal 
communication also includes the use of images, icons, and symbols. This communication requires skills such as understanding of the background of the audience, personal presentation, and body language.

Thus, the types of communication skills can be classified into two parts, namely the rough skills (hard skills) and fine skills / soft (soft skills). Written communication skills including skills in the rough (hard skills), while oral communication skills and non-verbal communication skills including fine / soft (soft skills).

Hard Skills Skill rough or inclined more easily controlled because of a technical nature, such as foreign language skills, operate machinery, playing certain musical instruments, and cooking. Meanwhile, soft skills visible from everyday actions. What is included in it? A lot, for example the ability of networking, collaborating with many people, communicating, interacting, leading, read the situation, your strategy, and so on.

Both types of these skills can be learned and practiced all the time. Furthermore, they must be combined in order to bring someone to the pinnacle of success. Imagine if someone known to be a technical master computer programming but never involved in important projects. Could be, his soft skills in terms of interaction, collaboration, and communication with other people must be questioned. Conversely, if someone looks good at bringing themselves and negotiating in front of many people, but when given the responsibility that requires hard skill turns out someone was disappointing, his reputation will be bad in the eyes of others.

The combination of expertise in the above collection (both hard skills and soft skills), equipped with the knowledge and experience. Attributes are required to show a good performance, so-called competence. Although competency could be built in the world of work, the elements in it as mentioned above, nurtured since school days. The better of their competence, the greater the opportunity to continue to jump-start a career.

Everyone in the world is definitely so desires. However, in reality, no one has managed to reach it 
and some have not managed to know even have felt like a failure in the pursuit of achievement targets important in life. An important factor that is often overlooked is not express soft skills in them. Soft skills play a role in a series of two- thirds of the competencies required for success. One after the other three are hard skills. From this division can only be viewed simply that soft skills have a role that is more than the hard skills.

\section{B. Method of Implementation}

1. Training Methods

Training methods, aimed to transfer knowledge and technology (science and technology) in addressing the issue through the exposure of the material for both partners. Which training implementation is planned in one room at the village hall. The method is defined by a team approach to overcome the problems and achieve the targets and outcomes that have been set as follows: 1) The ability to communicate well for the partners. 2) The communication skills simulations carried out by the members of the youth to practice public speaking to get accustomed to, do not get confused and do not stammer.
2. Simulations

Facilitate implementation team training using simulation games in which participants are required to perform in front of and explain the potential in the village and also the participants must be able to communicate with the other person about certain topics that had been prepared by the team.

\section{Result and Discussion}

The results of activities in the first training on oral communication skills, materials given on how to perform oral communication / oral well. Oral communication is the ability to explain and present ideas orally in a language that is clear (understandable) to diverse audiences. This capability includes the ability to package the words, using the appropriate style and approach to, and understanding of the importance of non-verbal cues in the oral communication.

Oral communication skills are very important, especially in the sphere of tourism. Some of the initial steps in to help how to improve verbal communication skills, in both planned and unplanned situations, 
such as: (1) Many read; much reading would increase the vocabulary (vocabulary) that will help us to express the ideas clearly and reduce the weaknesses of language skills, this can be done by reading or browsing the open Internet; (2) choose word which is popular, easy to understand, use in daily life. Avoid jargon that only certain understand by the circles; (3) Listen and show interest; listen and be interested! Strive more to hear or listen to the conversation of others rather than talk; (4) Notice of Non-Verbal Communication; Avoid jargon that only certain circles who understand; (3) Listen and show interest; listen and be interested! Strive more to hear or listen to the conversation of others rather than talk; (4) Notice of Non-Verbal Communication; Avoid jargon that only certain circles who understand; (3) Listen and show interest; listen and be interested! Strive more to hear or listen to the conversation of others rather than talk; (4) Notice of Non-Verbal Communication.

The second training is about non-verbal communication. Nonverbal communication occupies an important portion. Many effective verbal communication not only because the speaker not use non-verbal communication with both at the same time. Through non-verbal communication, people can take a conclusion about a conclusion about the various feeling people, pleasure, hate, love, miss and various other feelings. Relation to the business world, non- verbal communication can help communicators to further reinforce the message that submitted at the same time understand the reaction communicant receives the message.

Forms of non- verbal communication alone among them is, gestures, facial expressions, passwords, symbols, clothing sergam, color and tone of voice. For example: (a) A touch; A touch may include: shaking hands, holding hands, kissing, touching on the back, stroking, punches, and others. (B) The body movements; In nonverbal communication, body movements include eye contact, facial expressions, gestures, and posture.

The body movements are usually used to replace a word or phrase, such as nods to say yes; to illustrate or explain something; show feelings. (C) Vocal; Vocal or 
paralanguage is nonverbal elements in an utterance, namely how to speak. (D) Kronemik; Kronemik is a field that studies the use of time in nonverbal communication. The use of time in nonverbal communication include the duration of which is considered suitable for an activity, the amount of activity that we consider should be done within a certain time period, and the precise time (punctuality).

The latter is a simulation stage where the members of the youth are challenged to practice verbal communication and non-verbal in introducing the tourism potential warnasari village. We accompaniment performed by the Mrs. Yanti and students to provide simulation and examples of how to communicate the harmony between verbal and nonverbal.

\section{Conclusion}

Communication skills are the main skills a must-have to afford a

\section{REFERENCES}

Agus, M. Hardjana. (2003). Communication Intrapersonal Communication Interpersonal. Yogyakarta: Canisius. good relationship anywhere, such as in the social environment, schools, businesses and offices. Communication skills are also needed in the development of such enterprises to establish relations, marketing, promotion and also in the development and empowerment in terms of personal branding or cell empowering.

The most important thing in communication skills is understanding how to communicate in interaction, in this case the communication skills verbal and non-verbal is essential.

Communication skillstrain the people to participate actively in the interaction around it's precisely accurate. And indirectly Communication skills have become the main weapon which is powerful for people to be able to develop the tourism potential in the village Warnasari. And Communication skills can be applied not only to travelers fig but can be done in everyday life so that communication is effective.

DeVito, Joseph. (2011). Human communication. Tangerang Selatan : Karisma Publishing Group.

Djamarah, Saiful B. (2011). Psychology of Learning. Jakarta: Rineka Reserved. 
Griffin, EM. (2006). A First Look At Communication Theory. Sixth edition. Singapore.

Jamaliah Mohd Ali. (2001). Pro Forma 1309 TXEA Course (Skills and Cross-Cultural Communication Between), Kuala Lumpur: University Malaya.

Mulyana, Deddy. (2008). Effective Communication (A Crosscultural approach). Bandung: PT. Youth Rosdakarya.

Supratiknya. (1995). Interpersonal communication Psychological Review, Yogyakarta: Canisius.

Widjaja. (2008). Managing Organational Behavior. Jakarta: Grafindo. 